\title{
THE CONCEPTUAL FRAMEWORK OF CRIMES AGAINTS HUMANITY IN HISTORICAL CONTEXT AND INDONESIAN LAW
}

\author{
Maskun'
}

Abstract

The rapid ratification of the Rome Statute of the International Criminal Court (ICC) and the orderly election of its judges and prosecutor believe the radical nature of the new institution. Indonesia is one of countries that rejected the International Criminal Court (ICC) Statute. Indonesia's reason at that time was that Indonesian sovereignty would be threatened or its national security would be compromise. Interestingly, some of the crimes within the Rome Statute jurisdiction (Article 5 of the Rome Statute) had been adopted by Indonesia in its domestic law such as the Law No. 26 year 2000 concerning Human Rights Court. Jurisdiction of the Law No. 26 year 2000 is and genocide and crimes against humanity. The Law No. 26 year 2000 also adopts the idea of Ad hoc tribunal that is possible to apply ex post facto justice. Finally, it plays important role in order to protect Indonesian interest and to fulfill international community point of views.

Keywords: crimes against humanity, ICC, and the Law No. 26 year 2000.

\section{Introduction}

The rapid ratification of the Rome Statute of the International Criminal Court (ICC) and the orderly election of its judges and prosecutor belie the radical nature of the new institution. The Court has jurisdiction over genocide, aggression, crimes against humanity, and war crimes--crimes of the utmost seriousness often committed by governments themselves, or with their tacit approval. The ICC has the formal authority to adjudge the actions of high state officials as criminal and to send them to jail, no matter how lofty the accuser's position or undisputed the legality of those acts under domestic law.

Indonesia is one of countries that rejected the International Criminal Court (ICC) Statute. Indonesia's reason at that time was that Indonesian sovereignty would be threatened or its national security would be compromised. This has been thought firmly by Indonesia to justify its reasons in refusing to sign this statute.

${ }^{1}$ Lecturer of International Law, Faculty of Law, Hasanuddin University. Obtained Bachelor of Law (S.H.) from Hasanuddin University (1998), Master of Law (LL.M.) from University of New South Wales, Sydney-Australia (2004), and a PhD Candidate (Ph.D) from Hasanuddin University (2012), under supervised by Alma Manuputty as a Promotor, S.M. Noor and Juajir Sumardi, as co-Promotor respectively. The idea of this paper has connection indirectly to my dissertation, especially in developing elements of crime against humanity. 
However, some of the crimes within the Rome Statute jurisdiction (Article 5 of the Rome Statute) had been adopted by Indonesia in its domestic law such as the Law No. 26 year 2000 concerning Human Rights Court. Some of the Rome Statute provisions were incorporated in Articles 7 to 9 which apply to Genocide and Crimes against Humanity. Certain other crimes such as war crime and war of aggression were excluded.

The discussion of this paper focuses on the concept of crimes against humanity under Article 9 of the Law No. 26 Year 2000 Concerning Human Rights Court and Article 7 of the Rome Statute.

\section{Discuss and Analysis}

\section{A. Background of Crime Against Humanity}

The terminology crimes against humanity had been developed since Petersburg declaration 1868. As a concept of crime, it also was used in subsequent statements concerning World War I (WWI) and had been regulated based on the fourth Hague Convention 1907 concerning the Laws and Customs of War on Land. ${ }^{2}$ The Convention stated that "inhabitants and the belligerents shall remain under the protection of and subject to the principles of the law of nations, as established by the usage prevailing among civilized nations, by the laws of humanity, and by the demands of public conscience". 3 The Convention mentioned "the law of humanity" as one of "the authoritative legal sources of international law which supported the 1945 claim to prosecute and punish those who committed crimes against humanity".4

However, this terminology became "a crucial issue" when the Government of France, Great Britain, and Russia denounced the massacres of the Armenian Population by the Turkish government (1915) into Declaration of 28 May 1915. The declaration then asked to the Turkish Government to be responsible for its action as qualified as crimes against humanity. ${ }^{5}$

After World War II (WWI), the International Military tribunal (IMT) in Nuremberg was segregated the terms of crimes against humanity and war crimes. Article 6 of the Nuremberg Charter stipulates the following as crimes against humanity: “...murder, extermination, enslavement, deportation and other inhumane acts committed against any civilian populations, before and during the war; or persecution on political, racial, or religious grounds in execution of or in connection with any crime within the jurisdiction of the tribunal, whether or not in violation of domestic law of the country where perpetrated".

Although this was the first technical word of crimes against humanity under the Nuremberg Charter, this word was not treated by the Nuremberg Tribunal as a new concept. ${ }^{6}$ Control Council Law No. 10, dated 20 December

\footnotetext{
${ }^{2}$ Indonesian High Court, (2006). Guidance of Gross Human Rights Violations and Command Responsibility, Jakarta: Indonesian High Court in cooperation with Denmark Embassy, The Asia Foundation and ELSAM, p. 19.

${ }^{3}$ M. Cherif Bassiouni, (1987). Crimes Against Humanity. In M. Cherif Bassiouni. (1987). International Criminal Law Vol. III Enforcement. New York: Transnational Publisher Inc., p. 52.

${ }^{4}$ Ibid.

${ }^{5}$ R. Wright, (1948). History of the United Nations War Crimes Commission 29. In M. Cherif Bassiouni. (1987). International Criminal Law Vol. III Enforcement. New York: Transnational Publisher Inc., p. 51
} 
1945, then added imprisonment, torture, and rape to list of crimes against humanity under the Nuremberg Charter. Even though the list of crimes against humanity under the Nuremberg Charter was exhaustive and that under Control Council Law was illustrative; there was no practical difference between the two as the words 'other inhumane acts' in Article 6 of the Nuremberg Charter. $^{7}$

Article 5 of the Tokyo Charter, furthermore, stated similar list of crimes against humanity except religious grounds of persecution were omitted. This was because persecutions on religious grounds had not been committed on a large scale in connection with the Japanese war effort. ${ }^{8}$

\section{B. Under Customary International Law}

Crimes against humanity under customary international law can be found in the International Criminal Tribunal for the Former Yugoslavia (ICTY) and the International Criminal Tribunal for Rwanda (ICTR). ICTY explains that crimes against humanity could only be prosecuted against persons "when committed in armed conflict, whether international or internal in character, and against civilian population; murder, extermination, enslavement, deportation, imprisonment, torture, rape, persecution on political, racial and religious grounds, and other inhumane acts". (Article 5 of the ICTY Statute).

Under Article 3 of the ICTR Statute stipulates that crimes against humanity can be "committed as part of a widespread or systematic attack against any civilian population on national, political, ethnic, racial grounds". It has a discriminatory requirement in addition to some requirements in the Nuremberg Charter, the Tokyo Charter and the ICTY Statute. ${ }^{9}$ It was clear that the draftsmen of both the ICTR and the ICTY statutes followed the Nuremberg protocol. ${ }^{10}$

Similarly, the Security Council also recognized the applicability of crimes against humanity and segregated its definition in both statutes. Pursuant to the Security Council Article 5 of the ICTY Statute stipulated the obvious connection between crimes against humanity and armed conflict in which its connection was "irrespective subsequent development decoupling" crimes against humanity from war crimes and war of aggression, ${ }^{11}$ whilst such requirement is absent in Article 3 of the ICTR Statute but requires the elements of widespread and systematic attack. ${ }^{12}$

Bassiouni explains the differences between both Articles of both Statutes, as follows:

1. "The ICTY requires that the crimes be committed in armed conflict, whether international or internal in character whilst the ICTR does not require such element. p. 86 .

${ }^{6}$ Kriangsak Kittichaisaree, (2001). International Criminal Law. New York: Oxford University Press,

7 Ibid, p. 88.

8 Ibid.

9 Ibid, p. 89.

10 Kriangsak Kittichaisaree, (2004). Lecturer Note of Crimes Against Humanity. UNSW: unpublished, p. 10.

11 M. Cherif Bassiouni, (1999). Crimes Against Humanity in International Criminal Law 2nd Revised Edition, the Haque: Kluwer International Law, p. 194.

12 Ibid. 
2. The ICTR requires that crimes be part of a widespread or systematic attack whilst the ICTY does not require it.

3. The ICTR requires that the attack [be] against any civilian population (also required in ICTY, but adds) "on national, political, ethnic, racial or religious grounds". ${ }^{13}$

\section{Under the Rome Statute}

Basically, crime against humanity has been stated in the Article 5 of the Statute that stipulates crimes within the jurisdiction of the Court. One of the crimes is crime against humanity. The article 5 completely states:

1. The jurisdiction of the Court shall be limited to the most serious crimes of concern to the international community as a whole. The Court has jurisdiction in accordance with this Statute with respect to the following crimes:

(a) The crime of genocide;

(b) Crimes against humanity;

(c) War crimes;

(d) The crime of aggression.

2. The Court shall exercise jurisdiction over the crime of aggression once a provision is adopted in accordance with articles 121 and 123 defining the crime and setting out the conditions under which the Court shall exercise jurisdiction with respect to this crime. Such a provision shall be consistent with the relevant provisions of the Charter of the United Nations.

The Rome Statute furthermore had clarified and expanded the meaning and content of crimes against humanity in order to cover all areas that are not included in the Nuremberg Charter, the Tokyo Charter, the ICTY Statute and the ICTR Statute. The article 7 of the Rome Statute explains that crimes against humanity could be prosecuted "when committed as part of a widespread or systematic attack directed against any civilian population, with knowledge of the attack: murder; extermination; enslavement; deportation or forcible transfer of population; imprisonment or other severe deprivation of physical liberty in violation of fundamental rules of international law; torture; rape, sexual slavery, enforced prostitution, forced pregnancy, enforced sterilization, or any other form of sexual violence of gravity; persecution against any identifiable groups or collectively on political, racial, ethnic cultural religious, gender; enforced disappearance of persons; the crime of apartheid; and other inhumane acts".

It is therefore obvious that the article 7 expanded the concept by specifying and elaborating upon customary international law. ${ }^{14}$ First of all, Article 7 (1) of the Rome Statute specifies that a crime against humanity must be committed by perpetrator with the knowledge of the attack. ${ }^{15}$ Therefore, the accused person has to be aware that what he did is part of a widespread or systematic attack on a civilian population because without this knowledge, the accused person can be prosecuted for an ordinary crime, not crimes against

13 Ibid. .196.

14 Antonio Cassese, (2003). International Criminal Law. New York: Oxford University Press, p. 91. 15 Ibid. p.91. see also Kriangsak Kittichaisaree. Op cit. p. 91. 
humanity. ${ }^{16}$ Secondly, it clarifies the objective element of some offences implicitly so that according to Kittichaisaree it is not "necessary that the accused person have to know perfectly what will happen to victims". ${ }^{17}$ Thirdly, "it is not necessary to prove that the accused knows criminal policy or plan". ${ }^{18}$

An essential view in Article 7 of the Rome Statute is 'the meaning of crime against humanity in terms of the following acts when it was committed as part of a widespread or systematic attack directed against any civilian population'. There are two important of the crime:

1. Crimes against humanity must be related to a widespread or systematic attack. Under international jurisprudence, “-'widespread' means an attack directed against a multiplicity of victims, whilst a systematic attack means an attack carried out pursuant to preconceived policy or plan". ${ }^{19}$ However, Article 7 of the Rome Statute itself does not define what a widespread or systematic attack is. ${ }^{20}$

According to Bassiouni, the terms widespread or systematic attack actually has two obvious purposes:

(1). "To eliminate spontaneous or uncontrolled group conflict from the scope of the crime;

(2). To reflect the existence of state action or policy by state actors and the element of policy for non-state actors". ${ }^{21}$

In Tadic case, 'the issue of a widespread or systematic attack was examined whether the discriminatory intent was applied for all crimes against humanity or only for persecution.'22

2. Crimes against humanity must be related to attack directed against any civilian population.

Article 7 (2) (a) of the Rome Statute states that "attack directed against any civilian population means a course of conduct involving the multiple commission of acts referred to in paragraph 1 against any civilian population, pursuant to or in furtherance of a state or organizational policy to commit such attack". Kittichaisaree points out that "the attack is the event in which the enumerated crimes must form part, and there may be a combination of the enumerated crimes (for instance murder, rape and deportation) within a single attack. The attack involved is an unlawful act that may be violent or non-violent in nature, like apartheid or exerting pressure on the population to act in particular manner".23

However, an attack against the civilian population itself has to be explained clearly in order to define specifically who the civilian population is. Civilian population can be targeted not only in peacetime but also in armed conflict. Similarly, Kittichaisaree emphasizes further that, "civilian must be categorized not only from the general population but also members of the

16 Kriangsak Kittichaisaree. Op cit. pp.92-3.

17 Ibid. p. 91 . see also Antonio Cassese, op cit. pp.92-3

18 Ibid. p..91. see also Antonio Cassese, op cit. p.93

19 Ibid. p.96 \{Kayishema and Ruzindana, para.123. Cf. also Tadic judgement, para, 68; Blaksic, para

206.

20 Ibid. p.96

21 M. Cherif Bassiouni, Op.cit. p. 245.

22 Ibid. p. 245

23 Kriangsak Kittichaisaree. Op cit. p.94 
armed forced and resistance forces who are hors de combat by sickness, wounds, detention, or any other cause". ${ }^{24}$

Another criterion is the element of policy or plan. Article 7 (2) (a) of the Rome Statute states that "the attack is a course of a conduct "pursuant to or in furtherance of a state or organizational policy'”. ${ }^{25}$ This means that policy element can be related to the state or non-state actors in order to give policy to commit such attack against civilian population.

\section{Under Indonesian Law}

1. Background

B.J.Habibie who was appointed as a President of Indonesia in 1998 to replace Soeharto who was at the time was forced to resign by mass demonstration. Habibie at that time had a big obligation to cope with an economic ruin. However, in order to deal with it, Indonesia had to consider fully a lot of Human Rights problems especially East Timor in terms of getting some loan from IMF, CGI or World Bank. ${ }^{26}$ As a result, Habibie without consulting the Army announced two options to the East Timorese to exist as a part of Indonesia's provinces or become an independent country. ${ }^{27}$ The options were to be taken in a Referendum.

Astonishingly, the referendum's result showed that 78.5 percent of the population was in favor of independence and only 21.5 percent chose to retain it as a part of Indonesia. ${ }^{28}$ After the announcement of the result of the referendum by the United Nations, the condition of East Timor became uncontrolled in which serious violence had been started such as murder, extermination and forced transfer population. The violence had been committed by militias. The violence took place because East Timorese themselves segregated into two parties, the pro-autonomy group and the pro- independence group and both of them fought each other. ${ }^{29}$

The condition worsened in which the Indonesian National Army (TNI) and Republic Indonesia Police (POLRI) could not do anything to handle the situation. The UN resolved to allow UN intervention in Indonesia and The Secretary-General and the Security Council established INTERPET to take over some TNI and POLRI' posts. The occupying force started to excavate mass graves and to look for witness testimony in order to find evidence whether in the process of referendum grave violations had taken place. The investigation resulted in a finding that according to Mary Robinson, the UN Human Rights Commissioner, 'there had been a well-planned and systematic policy of killing, intimidation, displacement and destruction of property'. ${ }^{30}$

24 Ibid. p.95

25 Ibid. p.98.

26 EISAM, (2003). Discussion about the East Timor Human Rights Court, ELSAM, Jakarta, p. 2, (visited, 18 February 2004), < http://www.elsam.or.id/>.

27 Geoffrey Robertson QC, (2000). Crimes Against Humanity; The Struggle For Global Justice, Australia: Penguin Books, p 429.

28 Geoffrey Robertson QC, (2000). Op cit. p.430

29 EISAM, Op.cit. p.3. pro autonomy (militias) was supported by Indonesian National Army in which they were categorized based on their region such as Alfa team in Lautem; Saka/Sera in Baucao; Ablai in Manupahai; mahidi in Ainaro; Laksaurin Covalima; Aitarak in Dili; Sakunar in Ambeno; Besi Merah Putih in Liqisa; Halilintar iin Bobonaro; Jati Merah Putih in Lospalos and Darah Integrasi in Ermera [source: the Indonesian Commission of Investigation into Human Rights Violations (KPP HAM) , 2003].

30 Geoffrey Robertson QC, Ibid. 432. 
The implementation of re-agreement 'New York Agreement' between Indonesia-Portugal, the People's Consultative Assembly ratified and recognized the agreement. As a result, on 25 October, 1999, "the United Nations Security Council, by resolution 1272 (1999), established the United Nations Transitional Administration in East Timor (UNTAET) as an integrated, multidimensional peacekeeping operation fully responsible for the administration of East Timor during its transition to independence". ${ }^{31}$

However, the investigation by the UN is still ongoing to find some evidence. The UN formed Commission of Inquiry on East Timor (CIET) which makes a brief report about East Timor. Indonesia, therefore, tried to persuade the UN to get opportunity to do the investigation under the Human Rights National Commission (KOMNAS HAM). Its attempts succeeded to convince the UN and CIET assisted KOMNAS HAM. As a proof Indonesia's cooperation, the Indonesian government established a "Government Regulation [Issued] in Lieu of Legislation" (Peraturan Pemerintah Pengganti Undang-Undang or Perpu), a measure or act designed to prosecute crimes against humanity in East Timor that would be handled by KOMNAS HAM. ${ }^{32}$

The purpose of this law was that the Indonesian government intended to investigate crimes against humanity in East Timor through domestic law mechanism, and not international law. Finally, the Indonesian government established the Law No. 26 Year 2000 Concerning Human Rights Court in order to complete the Law no 1/1999 from its shortcomings.

\section{Court.}

The Contents of the Law No. 26 Year 2000 Concerning Human Rights

a. The Definition of Article 9 of the Law No. 26 Year 2000 Concerning Human Rights Court

Crimes against humanity in Indonesian Law are set out in Article 9 of the Law No. 26 Year 2000 Concerning Human Rights Court. that stipulates that crimes against humanity can be prosecuted "when committed as part of a widespread or systematic attack directed against any civilian population: murder; extermination; enslavement; deportation or forcible transfer of population; imprisonment or other severe deprivation of physical liberty in violation of fundamental rules of international law; torture; rape, sexual slavery, enforced prostitution, forced pregnancy, enforced sterilization, or any other form of sexual violence of gravity; persecution (assault) against any identifiable groups or collectively on political, racial, ethnic cultural religious, gender; enforced disappearance of persons and The crime of apartheid".

This definition is different from the Rome Statute because inhumane acts as part of the definition of crimes against humanity in the Rome Statute are excluded in the Law No. 26 Year 2000 Concerning Human Rights Court. This is so even if basically the Indonesian definition of crimes against humanity in the Law No. 26 Year 2000 Concerning Human Rights Court was adopted from Article 7 of the Rome Statute.

There is also no further explanation of the definition of crimes against hu-

31 UNTAET, Background Information, (visited, 18 February, 2004), <http://www.un.org/peace/ etimor/etimor.htm.>

32 ELSAM, Op.cit. p.9. 
manity in Article 7 (2) of the Rome Statute in the Indonesian law so in seeking their explanation reference must be had on the Indonesian Criminal Code (KUHP). However, the provisions under KUHP are different from Article 7 of the Rome Statute because the meanings of such crimes in KUHP still refer to traditional crimes not to extraordinary crimes. As an example, 'persecution' in the Rome Statute is interpreted by Indonesian language as 'assault'. This means that 'assault' cannot be equated as 'persecution' because obviously both of them are totally different in which 'persecution' has meaning stronger than assault. So that is why persecution in the Rome Statute was categorized as the most serious crimes against humanity. ${ }^{33}$

However, basically not only the explanation of the definition of Article 9 is an issue but also other problems like the concept of widespread, systematic attack and intention under this Article. This point is very important because it can cause a lot of different interpretations from judges that can affect the trial especially in assessing the burden of proof in crimes against humanity. As important elements in this definition, widespread, systematic attack and intention are not clarified to be able to properly categorize a crime as crimes against humanity or genocide. Comparatively to the Rome Statute, there is clear explanation about the intention. ${ }^{34}$

b. Element of Crimes Against Humanity.

i. Actus Reus

The actus reus of crime against humanity comprises of an attack that is inhumane in nature and character, causing great suffering, or serious injury to body or to mental or physical health. The inhumane act must be committed as part of a widespread or systematic attack against members of a civilian population.

The meaning attack in that term should be: (1) part of a widespread or systematic attack that conducted as multiplicity commission of acts. A widespread attack is an attack directed against a multiplicity of victims, whereas a systematic attack is an attack carried out pursuant to a preconceived policy or plan; (2) a widespread or systematic attack may not be a military attack; (3) the victims should any civilian population.

ii. Mens Rea

The specific element should be contained in each individual crime against humanity in order to transform a crime into a crime against humanity. In terms of it, the perpetrators must knowingly commit the crime in the sense that he must understand the overall or boarder context in which his act occurs. Without this knowledge, the perpetrators would have the mens rea for an ordinary crime, not a crime against humanity.

\footnotetext{
${ }^{33}$ Kriangsak Kittichaisaree. Op.cit. p.116.

${ }^{34}$ Article 30 of the Rome Statute stipulates mental element; '(1). Unless otherwise provided, a person shall be criminally responsible and liable for punishment for a crime within the jurisdiction of the court only if the material elements are committed with intent and knowledge; (2). For the purposes of this article, a person has intent where: (a). In relation to conduct, that person means to engage in the conduct; (b). In relation to a consequence, that person to cause that consequence or is aware that it will occur in the ordinary course of events.; (3). For the purposes of this article, 'knowledge' means awareness that a circumstances exists or a consequence will occur in the ordinary course of events. 'Know' and 'knowingly' shall be construed accordingly'.
} 
The knowledge will be examined on an objective level and factually can be implied from circumstances, and it is necessary that the accused must know exactly what will happen to victims. ${ }^{35}$

c. Exercise Jurisdiction

The human rights court has jurisdiction to investigate and prosecute serious human rights violation ${ }^{36}$ (Article 4 of the law) that were committed by Indonesian citizens not only in Indonesian territory but also outside its territorial jurisdiction (Article 5 of the law). This means that the Human Rights Courts can prosecute the perpetrator in both East Timor and Free Aceh Movement cases. However, the Human Rights Court has no obligation to investigate and sentence the serious human rights violations committed by someone under 18 years old when the crimes committed fall under Article 6 of the Law.

d. The Composition and Administration of the Court

\section{i. Judges}

Chapter VIII Article 27 (2) of the Indonesian Law states that the composition of human rights court judges is two judges from the Human Rights Court and three ad hoc judges. Ad hoc judges in the Human Rights Court may be appointed and disqualified by the Indonesian President after receiving some suggestion from the Supreme Court Leader. They are twelve persons of ad hoc judges in which they are appointed for 5 years and reappointed another five years (Article 28 of the Law).

One problem resulting from Articles 27 and 28 of the Indonesian Law is that ad hoc judges can be appointed from judges career and non-judges career ${ }^{37}$ This fact becomes worse because the election of judges career and non-judges career is not transparent to the public so that the public has no participation to give some advise and suggestion on who are capable in that position. ${ }^{38}$

Article 29 further explains the qualifications of ad hoc judges.

1. Indonesian Citizens;

2. Keep faith in God;

3. At least 45 years old but not over 65 years old;

4. With law background; ${ }^{39}$

5. Of sound body and mind;

6. With high moral character;

7. Loyalty to the Pancasila and UUD $1945 ;{ }^{40}$

8. With knowledge and care about the human rights issues.

\footnotetext{
${ }^{35}$ Indonesian High Court, Op.cit. p. 29.

${ }^{36}$ Article 7 of the Indonesian Law stipulates that Genocide and crimes against humanity are serious human rights violations.

${ }^{37}$ The non judges career means they are not judges at that moment but they may be lecturer (academicians)

${ }^{38}$ ELSAM, Op.cit. pp. 11-2.

${ }^{39}$ Other bachelor like the bachelor of Government Institute for Islam studies.

${ }^{40}$ Pancasila is the Indonesian basic principle in which Pancasila overrides national philosophy by illuminating the legal system which calls for confrontation to be avoided and for disputes to be resolved through deliberation and consensus, whilst UUD 1945 is the Indonesian constitutional.
} 


\section{ii. Prosecutors}

The prosecution of gross violation of human rights will be made by the Attorney General who can also appoint ad hoc public prosecutors to help him to prosecute the perpetrators (Article 23 (1) and (2) of the Law). The qualifications of ad hoc public prosecutors are the same as the qualifications of ad hoc judges (Article 23 (4) of the Law).

iii. The Register (known as Panitera)

There is no Article in the Law No. 26 Year 2000 Concerning Human Rights Court. that measures the registry. However, as chapter two Article two of this law states that the human rights court is established as specific court in Indonesian general judicature. ${ }^{41}$ Therefore, a person who holds responsibility for the administration and servicing of the court is Panitera by referring to the Indonesian administration court in all levels of the Court (like the registry in Article 43 of the Rome Statute).

2. Allegation of Crimes Against Humanity In East-Timor Allegation of crimes against humanity in East took place when a referendum conducted by the Indonesian government in 1999. According to Geoffrey Robinson, "between early January and late October at least 1,200 civilians, and perhaps as many as 1,500, were killed. Some were shot dead, while others were decapitated, disemboweled or hacked to death with machetes. Many were subjected to torture and ill-treatment. Women and girls were suffered rape and other crimes of sexual violence. The systematic violence fueled the forcible displacement of the population on a massive scale". ${ }^{42}$ In the period before the ballot, suspected supporters of independence were subjected to persistent threats and acts of violence by pro-Indonesian militia groups. ${ }^{43}$

Geoffrey Robinson furthermore stipulates that the worst of the violence followed the announcement of that vote on September 4. Over the next few weeks, Indonesian soldiers and police joined armed pro-Indonesian militiamen in a campaign of violence so sustained and so brutal that it shocked even those who had predicted a backlash. Before a UN-sanctioned military force arrived to restore order in late September, hundreds of people had been killed and an estimated 400,000 people - more than half the population - had been forced to flee their homes. ${ }^{44}$

Although the allegation of crimes against humanity had been committed in East Timor, one of the problems is Indonesia as a non-party of the ICC statute in which Indonesia does not have obligation to prosecute those crimes internationally or submit the perpetrators as international criminal. As a result of it, Indonesia only applies the Law No. 26 Year 2000 Concerning

\footnotetext{
${ }^{41}$ General judicature includes local court, high court and Supreme Court in terms of the hierarchy of Indonesian court.

${ }^{42}$ Geoffrey Robinson, (2003). East Timor 1999 Crimes against Humanity: A Report Commissioned By the United Nations Office of The High Commissioner For Human Rights (OHCHR). Los Angeles: University California. p. 1.

${ }^{43}$ Geoffrey Robinson, (2003). Ibid.

${ }^{44}$ Geoffrey Robinson, (2003). Op.cit.
} 
Human Rights Court in order to prevent the perpetrators committed those crimes to be prosecuted under international jurisdiction.

In addition, in order to satisfy the international community, the Indonesian Government established the Ad hoc human rights court (Article 43 (1) of the Law No. 26 Year 2000 Concerning Human Rights Court). However, the implementation of Indonesian law in East Timor case faces a lot of problems not only results from the definition itself, but also other points of view such as commander responsibility and the principle of fair trial.

The article 43 (1) of the Law No. 26 Year 2000 Concerning Human Rights Court states that the serious human right violation that took place before this law will be investigated and sentenced by Ad hoc human rights court. ${ }^{45}$ Therefore, East Timor case is investigated and sentenced by this court because it took place in 1999 before the Law No. 26 Year 2000 Concerning Human Rights Court released. However, all serious human rights violations proceeding would refer to the Law No. 26 Year 2000 Concerning Human Rights Court.

All gross violation of human rights that took place in East Timor at that time can be categorized as crimes against humanity. Those crimes were:
a. Murder;
b. Extermination;
c. Enslavement;
d. Deportation or forcible transfer of population;
e. Torture;
f. Enforced disappearances. ${ }^{46}$

\section{Conclusion}

Crime against humanity has a long history either in its definition or explanatory its elements of crime. It is also some cases coming based on that time. However, the most historical remember of the crime against humanity that took place in the past is massacres of Armenians to Turkish citizenship encouraged and condoned by the Turkish Authorities.

An allegation of crime against humanity conducted by the Indonesian Authority was taking place in East Timor post referendum. However, Indonesia could not be prosecuted to the Rome Statute because Indonesia is not a member of the ICC Statute. To fulfill the international community concerning to that crime, Indonesia then was enacting the Law No. 26 Year 2000 Concerning Human Rights Court. It plays important role in order to protect Indonesian interest and to fulfill international community point of views.

\footnotetext{
${ }^{45}$ See Muladi, (2011). Rome Statute 1998 concerning International Criminal Court: In Frame of International Criminal Law and its Implication to Indonesian Law. Bandung: PT. Alumni. p. 210.

${ }^{46}$ Human Rights National Commission (KOMNAS HAM) report January 2003 p. 6. KOMNAS HAM in its report explained further that all serious criminal act had been committed in East Timor since before and after referendum in which they had been committed by the Indonesian National Army (TNI), the Local government and militias that supported by TNI.
} 


\section{Bibliography}

Bassiouni, M. Cherif. (1999). Crimes Against Humanity in International Criminal Law $2^{\text {nd }}$ Revised Edition, The Haque: Kluwer International Law.

. (1987). Crimes Against Humanity. In M. Cherif Bassiouni. (1987). International Criminal Law Vol. III Enforcement. New York: Transnational Publisher Inc..

Cassese, Antonio. (2003). International Criminal Law, New York: Oxford University Press.

ELSAM. (2003). Discussion about the East Timor Human Rights Court, ELSAM, Jakarta, (visited, 18 February 2004), < http://www.elsam.or.id/>.

Indonesian High Court. (2006). Guidance of Gross Human Rights Violations and Command Responsibility. Jakarta: Indonesian High Court in cooperation with Danmark Embassy, the Asia Foundation and ELSAM.

Kittichaisaree, Kriangsak. (2001). International Criminal Law, New York: Oxford University Press. published. (2004). Lecturer Note of Crimes Against Humanity. UNSW: Un-

Muladi. (2011). Rome Statute 1998 concerning International Criminal Court: in Frame of International Criminal Law and its Implication to Indonesian Law. Bandung: PT. Alumni.

Robertson QC., Geoffrey. (2000). Crimes Against Humanity; The Struggle For Global Justice, Australia: Penguin Books.

Robinson, Geoffrey. (2003). East Timor 1999 Crimes against Humanity: A Report Commissioned By the United Nations Office of the High Commissioner For Human Rights (Ohchr). Los Angeles: University California.

Wright, R. (1948). History of the United Nations War Crimes Commission 29. In In M. Cherif Bassiouni. (1987). International Criminal Law Vol. III Enforcement. New York: Transnational Publisher Inc. 